\title{
BUILDING MAINTENANCE
}


By the same author

Building Quantities Explained

Building Economics

Building Technology

Civil Engineering Quantities

Municipal Engineering Practice

Civil Engineering Specification

Outdoor Recreation and the Urban Environment

Planned Expansion of Country Towns (published by George Godwin) 


\title{
BUILDING MAINTENANCE
}

\author{
IVOR H. SEELEY
}

B.Sc., M.A., Ph.D., F.R.I.C.S., C.Eng.,

F.I.Mun.E., F.I.Q.S., M.I.O.B.

Head of Department of Surveying

and Dean of the School of Environmental Studies

Trent Polytechnic, Nottingham 
All rights reserved. No part of this publication may be reproduced or transmitted, in any form or by any means, without permission.

First published 1976 by

THE MACMILLAN PRESS LTD

London and Basingstoke

Associated companies in New York Dublin

Melbourne fohannesburg and Madras

SBN 333171608

ISBN 978-0-333-17160-8 ISBN 978-1-349-02355-4 (eBook)

DOI 10.1007/978-1-349-02355-4

This book is sold subject to the standard conditions of the Net Book Agreement.

The paperback edition of this book is sold subject to the condition that it shall not, by way of trade or otherwise, be lent, re-sold, hired out, or otherwise circulated without the publisher's prior consent in any form of binding or cover other than that in which it is published and without a similar condition including this condition being imposed on the subsequent purchaser. 
This book is dedicated to my elder daughter LINDA

for her kind and sympathetic help and encouragement with my book-writing activities over many years 


\section{CONTENTS}

List of Figures $\quad$ xi

List of Tables xii

Preface xiii

Acknowledgements $\quad \mathrm{xv}$

1 Nature and importance of building maintenance 1

Concept of building maintenance; significance of building maintenance; liability for defects in buildings; maintenance needs; resources for building maintenance; nature of maintenance; research into maintenance; lives of buildings; technology of maintenance; consideration of maintenance at design stage; effect of metrication; relationship of capital, maintenance and running costs; economics of maintenance.

2 Building maintenance problems and their solution-I

Site conditions; foundation problems; settlement of buildings; shoring; waterproofing leaking basements; maintenance of paved and grassed areas; maintenance of fencing.

\section{Building maintenance problems and their solution-II}

Defects in wall claddings; brickwork; stonework; light claddings; structural frames; dampness penetration; condensation; chimney problems.

4 Building maintenance problems and their solution-III

Timber defects; floors; staircases; roofs; sound insulation; thermal insulation; vibration.

5 Building maintenance problems and their solution-IV

Joinery; corrosion of metals; plasterwork; external renderings; external wall tiling; internal finishes; decorations; glazing.

6 Building maintenance problems and their solution- $-V$

Plumbing; heating and hot water supply; air conditioning; 
electrical installations; gas installations; lifts; refuse collection from flats; drainage; safety; security; fire precautions; cleaning; repair of flood damage.

\section{Alterations and improvements}

Scope of alterations and improvements; modernisation of dwellings; conversion of other buildings into dwellings; prefabricated additions; sequence of alteration work; grants for improvements and conversions; rehabilitation or redevelopment; dilapidations; technical reports; proofs of evidence.

\section{Specification of maintenance work}

Sources of information; form of the specification; drafting of specifications; typical specification clauses; specifications for new work.

\section{Measurement and pricing of maintenance work}

Measurement of building work; principles and units of measurement; building estimates; approximate estimating; preparation of estimates by contractors; price build-up; pricing alteration works; checking builders' accounts.

\section{Tendering procedures and contract administration}

Nature and form of contracts; building contracts; types of building contract; tendering arrangements; government maintenance contracts; contract documents; parties involved in contracts; conditions of contract; conditions of contract for minor works; contract procedures.

\section{Building control}

Building Regulations; planning control; other statutory requirements; control of work in progress; easements.

\section{Planning and financing maintenance work}

Planning, budgeting and controlling the cost of maintenance work; planned maintenance; recording and dissemination of maintenance data; Building Maintenance Cost Information Service; maintenance manuals; costs in use; effect of taxation and insurance.

\section{Execution of maintenance work}

Choice between direct and contract labour; structure of building maintenance departments; maintenance depots; programming of maintenance work; organisation of maintenance work; programming and progressing maintenance work; training for maintenance; maintenance incentive schemes.

\section{Supervision of maintenance work}

Clerk of Works; site meetings; setting out; supervision of building work; records. 
Contents ix

Appendix 1 Metric conversion table 340

Appendix 2 Occupancy cost analysis - home for the aged 342

Appendix 3 Occupancy cost analysis-office block 346

Appendix 4 Classification of maintenance operations and repairs 350

$\begin{array}{ll}\text { Index } & 353\end{array}$ 


\section{LIST OF FIGURES}

2.1.1 Cracking arising from drying action of tree roots

2.1.2 Cracking associated with shallow foundations on shrinkable clay

2.1.3 Underpinning

2.1.4 Shoring

2.2.1 Dead shore

2.2.2 Raking shore

2.2.3 Detail at head of raker

2.2.4 Flying shore

7.1.1 Modernisation of dwellings-New Earswick

7.1.2 Modernisation of terrace house

7.2.1 Conversion of house into flats

7.2.2 Conversion of bedroom into bathroom

7.3.1 Conversion of village school into bungalow

7.3.2 Conversion of stable into cottage 


\section{LIST OF TABLES}

1.1 Approximate annual expenditure on maintenance work in Great Britain in 1969

1.2 Annual equivalent costs in use for typical buildings each providing 100 units of accommodation

3.1 Selection of mortars for brickwork and blockwork

4.1 Characteristics of wood-rotting fungi

4.2 Characteristics of some of the commoner wood-boring beetles

5.1 Some plastering defects and their causes and remedies

5.2 Mixes of renderings for various situations

5.3 Painting cycle costs on steelwork

5.4 Painting defects on woodwork

6.1 Weaknesses of various types of fire alarm systems

13.1 Control card

13.2 Tenants' request card

13.3 Job request form 


\section{PREFACE}

Building Maintenance has too often been regarded as the 'Cinderella' of the building industry. Yet in the early 1970 s Britain was spending over $£ 2000 \mathrm{~m}$ per annum on the maintenance of buildings and about 40 per cent of the building labour force was engaged on this class of work.

The maintenance of the built environment affects everyone continually, for it is on the state of our homes, offices and factories that we depend not only for our comfort, but for our economic survival. The building stock in the United Kingdom had an estimated replacement value of about $£ 120000 \mathrm{~m}$ in 1973 and this alone indicates the importance of effective upkeep. There is still a pressing need for the improvement of large numbers of older but substantial dwellings which lack some of the basic amenities.

Maintenance starts the day the builder leaves the site. Design, materials, workmanship, function, use and their interrelationships, will determine the amount of maintenance required during the lifetime of the building. Furthermore, the client's economic interests may work against the elimination of high maintenance costs in the building design. Case studies undertaken by the DOE Committee on Building Maintenance have shown that about one-third of the maintenance work on the buildings investigated could have been avoided if sufficient care had been taken at the design stage and during construction. The design faults resulted either from failure to appreciate how various constructional details would perform in use, or because certain parts of the building that failed through normal wear and tear could not be replaced without extensive repairs to adjacent parts. A spokesman for the Building Research Establishment has also commented on the frequent failure by designers to make use of authoritative design guides such as British Standards and Codes of Practice, and of the tendency to adopt a careless attitude to detail design.

The building fabric has to satisfy different user needs and occupational factors. The designer should identify what performance is required from the fabric in terms of weathertightness, noise reduction, durability, resistance to heat loss and other relevant criteria, in addition to comfort and visual requirements. Many of the design faults which result in high maintenance expenditure could conceivably be avoided if a maintenance manager, or someone with similar technical knowledge, joined the design team. Not many architects or builders revisit their jobs after the expiry of the defects liability period and few have a continuing responsibility for maintenance.

There is rarely an obvious end-product in building maintenance, and the effect of neglected industrial buildings, for instance, will seldom be as serious for the 
owner as the disruption caused by a breakdown in production following neglect of plant maintenance. For this reason building maintenance is often considered as one of the first items for budget cuts when retrenchment becomes necessary. Indeed some building owners regard maintenance costs as part of the debit side of the balance sheet and an erosion of legitimate profits, because they fail to appreciate its true value. It is, however, only common sense to ensure that when a decision is made on maintenance work, account is taken of the aggravation of the defect which is likely to occur if work is delayed, with consequent increase in cost.

The satisfactory maintenance of a dwelling makes it fit to live in, but the occupant may have a very narrow view of what this entails. If the household equipment works, the internal decorations are cheerful and the external appearance respectable, he will probably be satisfied. The maintenance manager must take a deeper view-loose roof tiles, unsound timber, defective damp-proof courses or powdering mortar are symptoms of a state of disrepair which cannot be cured by superficial measures. Unless basic repairs are carried out in time, the property will become damp or its structure will deteriorate so that normal jobbing repairs and repainting are no longer sufficient to restore even an appearance of wellbeing.

Building maintenance is assuming increasing importance which is shown by the holding of several large national conferences on this subject, the mounting of diploma and postgraduate courses in maintenance management, and the considerable volume of maintenance research by government departments, universities and polytechnics, apart from the valuable work undertaken by the leading professional bodies connected with the building industry. Nevertheless, the DOE Committee on Building Maintenance has drawn attention to the need to give increased emphasis in appropriate degree and professional examination curricula to building maintenance. The Committee believes that the main subject areas that need to be covered are the relationship between the design and performance of buildings and services; the organisation and control of maintenance work; economics and finance; law and liability; and technology. These subject areas form the core of this book which it is hoped will be of value to students and practising surveyors, builders, architects, estate, housing and maintenance managers, and environmental control officers alike.

Effective building maintenance requires the correct diagnosis of defects, and implementation of the correct remedial measures, all based on sound technical knowledge, otherwise there can be additional waste of materials, labour and money since the work will in all probability have to be done again. We need more uniformity in the method of recording maintenance data and greater feedback of information on the performance of materials and running costs of buildings in particular. The increased use of maintenance manuals and more regular maintenance inspections and schemes of planned maintenance will assist in producing more efficient maintenance. Effective maintenance control requires the formulation of sound plans, recording of performance, comparison of performance with the plan and the taking of corrective action where appropriate. Finally there is the need to make better use of available resources. 


\section{ACKNOWLEDGEMENTS}

The author acknowledges with gratitude the willing co-operation and assistance received from many organisations and individuals, so many that it is not possible to mention them all individually.

Crown copyright material is reproduced from BRE Digests by permission of the Director of the Building Research Establishment; in this connection it should be mentioned that copies of the digests quoted are obtainable from Her Majesty's Stationery Office, PO Box 569, London SE 1 or any bookseller.

The Building Maintenance Cost Information Service Ltd, the Property Services Agency and Kent County Council have kindly given permission for the inclusion of the occupancy cost analyses (appendixes 2 and 3) and other valuable supporting information. Tables 13.1, 13.2 and 13.3 are based on forms prepared by Bath City Council.

Drawings of improvement schemes are based on the following published articles

J. H. Cheetham, Building Trades fournal, 9, 23 and 30 September 1966

J. A. Foreman, Building Trades fournal, 3 May 1968

The Louis de Soissons Partnership, Architects' fournal, 30 January 1974

Reference has been made to articles in various technical journals, of which Building Maintenance deserves special mention. The proceedings of the DOE National Building Maintenance Conferences have also provided valuable sources of information. Some extracts of material prepared by the author for the Ellis School of Building and NALGO Correspondence Institute and from Building Technology have been incorporated.

The author is indebted to Celia Farmiloe for so ably typing the manuscript, to Jack Preite for preparing the final drawings of high quality and to Pamela Footitt, deputy librarian at Trent Polytechnic, for enthusiastically obtaining a wealth of supporting data. Grateful thanks are due to the publisher for abundant help and consideration throughout the production of the book. 